\title{
Counting Carbon: calculative activism and slippery infrastructure
}

\begin{abstract}
The environmental movement in the global North is in a state of impasse. It appears that despite the renewed international focus on climate change, and the actions of innumerable social movements, a 'solution' to the problem appears as one, without a viable solution. It is the contention of this paper that climate change has no clearly viable solution as it is a seemingly impossible problem. This paper investigates how the problem of climate change is constructed as a global object of political action and how it functions to render politics into a matter of calculative action, one that seeks - but fails to take hold of a slippery carbon infrastructure. It concludes by suggesting one possible solution to this dilemma is to turn away from the global scalar logic of climate change and towards a situated focus on questions of infrastructure, or what Dimitris Papadopoulos calls "thick justice".
\end{abstract}

Keywords: thick justice, failure, climate change, infrastructure, activism, energy 


\section{Introduction}

In recent years it seems as though climate change has come back onto the international political agenda with a vengeance. China's massive investment in renewable energy infrastructure, persistent problems with extreme fossil fuel extraction, talk of stranded fossil fuel assets, the various attentions of Presidents, Prime Ministers and the Pope, and the naming of the Anthropocene have all contributed to the sense of a public revival of interest in climate change as a political problem across much of the global North ${ }^{\mathrm{i}}$.

However, despite the renewed focus on climate change and numerous environmental 'wins', traction appears elusive. No matter what action is taken or policy is implemented it never appears to be sufficient. Or more accurately, it is never said to 'add up' to anywhere near enough. One example: at the time of writing two separate accounts of national UK greenhouse gas reduction pledges have been published setting out how existing pledges of emission reductions fail to adequately address climate change (Reuters 2015). Both show that the existing pledges add up to more than $2^{\circ} \mathrm{C}$ (one suggests they add up to a potentially catastrophic $3.5^{\circ} \mathrm{C}$ ) ${ }^{\mathrm{ii}}$. And this is the accounting of promises actually existing national policies add up to $3.3-3.8^{\circ} \mathrm{C}$ by 2100 .

As writer-activist Bill McKibben (2013) and climatologist Kevin Anderson (2012) have famously suggested, there is a brutal mathematics to climate change, one that necessitates almost unimaginably vast socio-economic transformations on a global scale within a very short timeframe. Anderson's work is exemplary in that he argues that emissions needed to peak in 2015 for there to be an even chance of climate change being contained to 'only' $2^{0} \mathrm{C}$ (ibid). It has been suggested that it is in actual fact too late to do anything more than contain the future damage of climate change, and work towards adaption on a hotter planet (Hamilton 2010; McKibben 2010). Thus the brutality of the mathematics of climate change is compounded by a 'brutal' sense of what we could call scientific realism ${ }^{\text {iii }}$, where hope resides not in averting disaster but minimizing its fallout ${ }^{\text {iv }}$.

Much faith is placed in national governments to act, either to arrest or mitigate future climate change. This faith appears to have waned after the failed 2009 international climate change negotiations in Copenhagen, and this crisis of faith has only deepened over the intervening years as national governments have singularly failed to negotiate an international climate change treaty or realize mitigation policies that would successfully contain future global warming to less than $2^{0} \mathrm{C}$. Here my focus is not on the shortcomings of governments or transnational corporations however. Rather I will explore a different supposition: namely, what if we suppose that at least part of the problem with climate change is how it is constituted as a matter of political concern, that the construction of climate change as a socio-scientific fact limits how we can act politically on climate change? That is, what if the problem with climate change is the problem itself?

This paper sets out to explore how climate change is formed as a matter of political concern within grassroots environmental movements through an exploration of one particular instance of environmental direct action in the UK: the No Dash for Gas power station occupation in 2012. I argue that the climate change imaginary (Hulme 2009; Luke 2015) at work within the UK environmental milieu configures climate change as a kind of mathematical object. While this mathematical rendering of climate change enables taking hold of it as a political issue (Stengers and Pignarre 2011) despite its 
abstract and global nature (Jasanoff 2010), it produces a globalizing synoptic logic, one that effectively disables localized action on climate change (Clark 2012).

The shortfall between specific actions that fail to add up and the global scale of climate change induces a form of calculative pragmatism, one that pushes questions of radical social transformation to one side as ever-more achievable reductions in $\mathrm{CO}_{2}$ are sought out. I argue this forms the basis for the current impasse in climate change politics in the global North ${ }^{\mathrm{v}}$ and requires abandoning climate change as a political object in favor of an emphasis on questions of what Dimitris Papadopoulos has called "thick justice" (2010:147).

As such this paper sits at the intersection of two bodies of research. This first is the existing field of work on social and environmental movements within radical geography, where one of the key concerns is how social movements and affected communities can and do create the capacities to act powerfully on the worlds they inhabit, and how the future is produced as a contested space (Chatterton, Featherstone and Routledge 2013; Featherstone et al. 2012; Feigenbaum, Frenzel and McCurdy 2013; Neville and Weinthal 2016; North 2011; Plows 2008; Saunders and Price 2009). As I set out in the following section, much of this field takes up an affirmationist orientation, one that produces an analytical lacuna. The second body of research is the emerging field of infrastructure studies, one that takes in works from geography, anthropology and science and technology studies (Anand et al. 2012; Furlong 2010; Howe et al. 2015; Jensen and Morita 2015; Larkin 2013; Star and Ruhleder 1996). Where the first often focuses on human actors, the second explores how the material work works to condition the kinds of actions that can be taken, and what forms of life are made possible (or impossible) through socio-technical infrastructure (Papadopoulos 2014).

\section{The affirmationist gap}

To suggest that the current impasse in climate change politics is in part due to how climate change as a problem has been constituted is not to suggest that environmental activism is either dishonest or misusing 'the science'. Indeed, much of the literature on UK environmental activism and produced within the movement itself openly debates how climate science (and climate activism) are to be interpreted (Saunders 2012; Shift and Dysophia 2010). Taking my cue from environmental historian Peter Hay, I contend that modern environmentalism has always been in deep conversation with scientific literature (2002:47) and that there is a porosity between the milieus of environmental activism and environmental science.

It could be suggested that to even question the composition of the problem of climate change is to court the denial industry and the interests arrayed in opposition to action on environmental issues (Oreskes and Conway 2011). Such a stance would reflect the disavowal of uncertainty by climate scientists themselves (Shackley and Wynne 1996). In both instances there is an apparent felt need to affirm: in the first instance, to affirm that environmentalism is working; in the second to affirm that climate change is a fact, and that this fact necessitates active concern.

While these are not a single affirmation, they share a common political orientation. This common orientation combines a suspicion of negativity grounded in the fear of its totalizing effects with a form of politics that ontologises resistance as necessarily being constructive and affirming (Noys 2010:ix-xii;9-13). This affirmationist stance denies any role to destructive or negative gestures, thus making for brittle modes of political praxis. 
Such a stance makes for a defensive atmosphere amongst climate scientists. The construction of scientific facts is especially contestable within climate science because of the way those facts are articulated through processes of approximation and abstraction (Edwards 2010; Jasanoff 2010). The facts of climate change manifest as a range of possible futures - emissions pathways and possible temperature variations. Translating these matters of fact into matters of concern is thus necessarily an open process, one that resists closure as would be afforded by more concrete facts that would function to effectively silence critics (Demeritt 2006:472; Latour 2004b; Stengers 2000).

At stake here is the political question of who can make nature speak, and who will be listened to when doing so thus conferring social legitimacy (Demeritt 2006; Stengers 2000:81). That climate change is a fact is, in the UK, in little dispute (Rogers 2013). What is in dispute are what the facts 'mean' (Demeritt 2006:472). As suggested by Mike Hulme, what they 'mean' is deeply entwined with economic and political calculation with the question of what sort of socio-economic system humanity will inhabit in the future (2009). And not just the future but also in the uneven present (Parenti 2011). Climate change as a fact is not only a matter of approximation and abstraction, but also of the economic calculus of emissions pathways and the energy intensity of production methods, as outlined by innumerable environmental and scientific authors (Anderson 2013; Hamilton 2010; Hulme 2009; Inman 2010; Klein 2014; Monbiot 2007; Spratt et al. 2009; Stern 2006; World Bank 212). To resist uncertainty within climate science then could be said to be a means of defending a specific formulation of climate change as a problem, one that necessitates dramatic socio-economic transformations including the end of global economic growth (Jackson 2011; Klein 2014; Spratt et al. 2009). Affirmationism thus appears as a device for reducing the range of how the fact of climate change can be constituted as a political concern. This approach to climate change is common not only to the articulation of climate science, or amongst climate activists but extends more broadly to radical scholarship that contends with the practices of environmental politics.

Current literature on climate change politics and activism in the UK sets out how recent campaigns and protests can be understood to have been successful despite the lack of success on the issue of climate change itself (i.e., Chatterton, Featherstone and Routledge 2013; Plows 2008; Saunders and Price 2009). For the most part the question of success or failure is not dealt with in the terms set by various campaigns or organizational goals, which often state that arresting climate change is the primary objective of taking action. Rather, what I called affirmationist literature instead focuses on the positive outcomes of climate activism while avoiding the question of success or failure vis-à-vis climate change itself.

The affirmation of climate change activism is undertaken through a focus the positive transformative effects of environmental activism on social and political capacities (Featherstone 2013). The political framework of climate activists is said to provide an alternative antagonistic political framework focused on global solidarity and commonsbuilding (Chatterton, Featherstone and Routledge 2013; Featherstone 2013), one that is prefigured through the specific organisational forms used by climate activist movements (Feigenbaum, Frenzel and McCurdy 2013; Frenzel 2014).

While this literature acknowledges the ambivalences of existing climate activism, this has not led to calls for it a substantive transformation (Sealey-Huggins 2016). And while there have been numerable articles exploring the tensions within climate activism between 'reformist' and 'radical' positions (Bomberg 2012; Harding 2015; Saunders 2012; 
Saunders and Price 2009), by and large these pieces have focused on the internal organizational dynamics of climate activism, or the social composition of environmental activism as a movement, as the cause of political impasse and tended to concluded that what is required is to fuse or combine the varied modes of political action, often at a greater 'scale', rather than revisit their collective failures (Bergman 2014; Kenis 2014; North 2011; North and Longhurst 2013; Saunders 2012). Many conclude that despite the ambivalences and (often undiscussed) failures of climate activism, that it has had a transformative effect either on the forms of oppositional politics or on broader political frameworks within which climate change is discussed (Barry and Quilley 2008; Bomberg 2012; Chatterton, Featherstone and Routledge 2013; Featherstone 2013; Frenzel 2014; McGregor 2015; North 2011; Plows 2008; Saunders 2012; Saunders and Price 2009).

By making an explicit connection to a vision of activism as active citizenship, activism is additionally examined as the building of political and material capacities over generations (Plows 2000; 2008; Rootes 2011). Place-based activism here is often explicitly bound to the positing of a broader environmental movement, where the 'local' is understood tacitly as part of a more expansive process of social transformation (Neville and Weinthal 2016), when not cast as an impediment to the realization of a more powerful climate movement (North and Longhurst 2013). This is said to be part of a broader empowering of civil society vis-à-vis governmental and market actors, one that enables civil society to move both to take appropriate action on issues such as climate change.

These approaches to the transformative power of environmental activism suggest that environmental activists produce change either as an intervening force that transforms what is considered to be possible (McGregor 2015) or as a constituent force that builds autonomous institutions of social power (Barry and Quilley 2008; Saunders and Price 2009). While this body of literature is not entirely uncritical (i.e., Saunders 2012) it acts to affirm the idea that climate activism is positively engaged in social transformation despite the shortcomings of existing action on climate change, and what is required for greater 'success' is, if anything, an intensification and scalar expansion of existing forms of climate activism.

This body of work mirrors many of the claims of climate activists themselves, where while the explicit targets of actions and campaigns has varied over the past decade or more, the tactics and strategies remain essentially the same - prefigurative organisational forms and protest camps and spectacular direct actions (Feigenbaum, Frenzel and McCurdy 2013). The lack of variation and the question of success or failure was openly addressed within the climate activist milieu (Camp 2010; Shift and Dysophia 2010). These moments of reflexivity did not translate into negativity however: neither the constitution of the fact of climate change, its 'brutal mathematics', nor activism as an appropriate form of political action on climate change have come into open question in light of previous failures. What has come to be the fault line of activist and academic contention in many cases is the question of working against (radically) or within (reformism) existing institutional frameworks (Saunders 2012; Shift and Dysophia 2010).

The exception to the general tone of affirmationism within the literature centers on the postpolitical role of science (Bryant 2016). This body of geographical work is largely conducted through an account of environmentalism as a form of postpolitics (Swyngedouw 2008; 2010; 2013). Postpolitical here signals the transformation of environmental political praxis from one concerned with 'properly' political questions to one focused on technical policy solutions, framed within neo-classical and neoliberal economic orthodoxy, that are presented in place of properly political debate and 
discussion (Crouch 2012; Valentine 2005). While a much contested concept (Dean 2009; McCarthy 2013; Valentine 2005), this approach has been particularly used in relation to Climate Camp (Bowman 2010; Schlembach 2011; Schlembach, Lear and Bowman 2012), producing some useful insights on how climate science discourse was mobilised by climate activist network Climate Camp to often stifle debate or internal dissent, as well as outlining some of the lived social and political tensions of the Camp, indicating how science introduced a degree of friction into the political praxis of climate activism vis-àvis the Camp.

However the conversation between climate science and environmental activism in the $\mathrm{UK}$ is little explored beyond noting the adoption and translation of science into activist policy (Schlembach, Lear and Bowman 2012). The processes of scientific knowledge constitution and the mobilisation of knowledge within activist praxis is under theorised, with the result being an account of UK environmental activism that lacks any substantive discussion of how scientific knowledge of climate change is produced or of the role of environmental activists in producing such knowledge. In addition, the postpolitical analysis tends to treat science as a specific kind of exhaustive fact, one that paralyses political activism and that can only imply technical or policy solutions, an account at odds with the long history of environmental studies and history, as well as that of science and technology studies (Castree 2014; Demeritt 2001; 2006; Dryzek 2005; Fortun 2001; Haraway 1991; 1997; Hay 2002; Jasanoff 2010; Latour 2004a). As such, while presenting a welcome intervention into the collective framework of environmental praxis, this second tendency fails to offer a sufficiently critical account of the constitution of the facts of climate change and thus of the object of climate activism. Thus the postpolitical literature works to evacuate politics from science, deepening the fact-concern divide and uncoupling political practice from scientific fact.

\section{Occupying the climate}

In late October 2012, around 20 activists broke into and occupied West Burton gas-fired power station in Nottinghamshire. 11 of the activists scaled one of the power stations cooling towers, making camp at the top. The power station operators shut down the cooling tower, while the protestors begun to claim victory via their twitter account:

“[we are] preventing emissions every hour" (12:32 PM - 30 Oct 2012)

"Every day we're up here we're preventing 2371 tonnes of CO2 emissions - the amount an average home takes 182 years to emit" (4:20 AM - 1 Nov 2012)

"At $7 \mathrm{am}$ this morning our occupation had prevented 10,000 tonnes of $\mathrm{CO} 2$ from polluting the atmosphere!" (2:09 AM - 2 Nov 2012)

The aim of the occupation was to both stop the construction of the gas-fired power station and to "expose the madness of a government that is totally in the thrall of the big energy companies" (NDG protestor, Jasiewicz 2012). It was a two-fold action that sought to directly stop greenhouse gas emissions (present and future) and at the same time produce a public spectacle that sought to pressure government into changing its approach to energy policies.

"As our name suggests, No Dash for Gas planned this action to bring attention to the coalition's reckless plans to build a new wave of dirty gas power stations. The energy and climate change secretary, Ed Davey, recently announced that the government wants to encourage as many as 20 of these plants to be constructed by 2030. But as the government's climate adviser, the Committee on Climate Change (CCC), has warned, 
this risks pushing the UK out of reach of meeting its legally binding carbon reduction targets."(NDG protestor quoted in Carter 2012: un pg)

"The climate change bill commits us to $80 \%$ initial reductions by 2050 with $60 \%$ by 2030, so building a new generation of gas fire power stations will make it impossible to reach these targets." (NDG protestor quoted in Paget 2012: un pg)

The chimney occupation was the UK's longest power station occupation (Wainwright 2012c). It was also the first and only time climate change protestors had shut down a power station (ibid), and thus could be called one of the most successful climate change direct actions in UK environmental history. The organizational precursor to No Dash for Gas (NDG) was Climate Camp, an organization that existed for 5 years and organized numerous mass actions in the UK (Camp 2009). Climate Camp had unsuccessfully attempted on numerous occasions to disrupt the functioning or shut down power stations over its five-year history, starting in 2006. The environmental non-governmental organization Greenpeace had also previously scaled power station chimneys, most notably at a power station in Kent, yet also without disrupting their operations (Adam and Tran 2009).

"Our motivation for this protest is to try and stop this government from locking us into a dependency on gas for the next 30 years" (NDG protestor, quoted in Wainwright 2012a)

NDG explicitly focused on how the future is organized through government energy policies; specifically, they treat the future as something materially produced in the present through infrastructure. Both climate change and infrastructure organize and 'lock in' particular futures. Greenhouse gases take centuries to be fully reabsorbed into the Earth's carbon cycle (Archer 2009). Hence when the carbon cycle is disrupted it transforms the very conditions of life for generations to come. Here we could outline how climate change will produce lower crop yields and shortages of fresh water, making for a thirstier and hungrier world, of that there will be increases in severe storms and droughts, making for a harsher world, or even that the world of the future will be much less diverse, with fewer species, degraded habitats and emptier oceans, making for a silent earth (Lynas 2008; McKibben 2010).

In all these ways and more climate change shapes what kinds of lives people can live on Earth, and thus is a matter of what Papadopoulos calls "thick justice" (2010:137). Thick justice signals a shift away from liberal humanist conceptions of justice as a matter of redistribution and correction within existing material conditions towards the question of material conditions themselves (ibid:145). Thick justice focuses on how infrastructure conditions the lives we can live - on the question of what forms of life infrastructure enables and disables, produces and inhibits (ibid). Thick justice is also a matter of addressing the question of sacrifice or abandonment of some peoples and lifeworlds in order to maintain others (Povinelli 2011), the role of making absent or silent certain peoples and lives within 'legitimate' political debate (Braun and Whatmore 2010:76), and of recognizing that to be for some worlds is to necessarily be against others (Haraway 1997:37).

Thick justice denotes a form of activism (Papadopoulos 2010:137) that focuses on the constitution of material conditions themselves, on what forms of life infrastructure enables and disables, produces and inhibits (Jensen and Morita 2015; Star and Ruhleder 1996; Winner 1986). It focuses attention on how the conditions of life produced through infrastructure are a crucial site of contestation and resistance (Boyer forthcoming; Howe 
et al. 2015). And, going beyond resistance, it asks what an energy infrastructure molded by thick justice would look like and how politics and political agency is transformed by material activist practices (Papadopoulos 2014).

When the UK government sets out a program of power station construction they set out a framework for how people in the UK will engage with and be constituted by energy production for years to come, effectively 'locking in' a particular form of life organized around and through a centralized energy grid powered by fossil fuels.

\section{How to count carbon}

What makes climate change as a problem legible is the mathematics of a particular particle - carbon dioxide $\left(\mathrm{CO}_{2}\right) \cdot \mathrm{CO}_{2}$ functions within the climate imaginary (Cornerhouse 2010; Luke 2015) as a kind of universal equivalent that enables the commensuration of quite different and disparate processes, objects and matters of fact (Demeritt 2001; 2006). While $\mathrm{CO}_{2}$ can and does function as a commodity fetish (Cornerhouse 2010; Swyngedouw 2013:4-5), within government policy and environmental politics it is more accurate to say that it functions as what Bruno Latour calls a factish (2010).

A factish differs from a fetish in that it retains the trace of its manufacture (Haraway 1997:136; Latour 2010:2-3), unlike the commodity fetish that obscures its origins within the relations of production (Marx 1990). As such, a factish does not mystify its origins. It retains a power over its creators despite its opacity however, one that derives from its functionality: it is a pragmatic construct. A factish enables one to make the world 'speak' in a particular way (Stengers 2000), to engage materially with a specific problem. And in doing so to shapes not only the kinds of questions that can be asked but crucially legitimates a particular line of questioning as factual. In producing itself as a 'natural truth' through experimental success, a factish constitutes itself as a necessary fiction securing its discursive and sociotechnical power as a matter of fact (Latour 2004b). When matters of fact such as climate change are successfully made into matters of concern (ibid) this sociotechnical power is drawn into broader socio-political and policy discourses.

How something comes to be a necessary fiction shapes the capacities it has as a factish. $\mathrm{CO}_{2}$ is a necessary fiction insofar as climate science requires the production of a means to calculate and experiment with the Earth's climatic system. Climate change is a planetary phenomenon, one that is not directly available to experience but only knowable through computer models (Edwards 2010; Weart 2008). As such it is inseparable from the instruments and sociotechnical relations through which we come to know it Jasanoff 2010; Stengers 2000): in particular, the computer models that we use to simulate the Earth's climate. But more than this our knowledge of climate change is in certain senses inseparable from broader processes of globalization. Climate change is a novel ontological problem (Blok, Nakazora and Winthereik 2016:1), "an object of massive scientific attention, transnational political contestation, and a focal point for emerging legal-ethical ideals of globalism" that produces the phenomenon of a global environmental problem that manifests within a global ecological regime. The sociotechnical knowledge's, collaborations, research programs and inter-governmental projects that constitute the basis for climate change science is an outcome of processes of globalization (Edwards 2010). As such there is a shared envisioning framework that binds the calculative logic of climate change science to the hierarchical orderings of 
globalization where the local is always subordinated to global processes and projects (Massey 2014).

To make the calculations of the computer models work what is required is a calculable 'proxy' for the various processes at work within the Earth-system (Cornerhouse 2010:37). While $\mathrm{CO}_{2}$ comprises less than half of all greenhouse gases it comes to stand in for all of them as well as the geological, biological and meteorological processes out of which emerges climate change as a environmental problem (Archer 2009:38). $\mathrm{CO}_{2}$ is used to 'think' and see climate change and frames how we understand and then act on it as a problem (Luke 2015). Climate change is mathematical and abstract in nature as a problem (Hulme 2009; Jasanoff 2010:234), and this shapes environmental praxis in two ways. First it produces a global scale of reference - all actions must make sense and refer to the global scale of climate change. Secondly it creates a framework for political action on climate change: one counts carbon emissions in order to reduce them.

The logic of climate change activism sets out from a global frame of reference and works 'down' towards specific responses to climate change through a process of carbon calculus - by literally 'counting carbon' in order to figure out how to reduce $\mathrm{CO}_{2}$ emissions step by step.

\section{Calculative action at work}

"The occupiers have so far prevented 2,371 tonnes of $\mathrm{CO}^{2}$ emissions a day by shutting down the one working chimney. This is equivalent to the energy that an average home uses for 182 years, or taking 465 cars off the road for a year." (Wainwright 2012b)

"We stopped 20,000 tonnes of $\mathrm{CO}_{2}$ being emitted, prevented any construction work on the site for a week and got our message about how reckless and ridiculous George Osborne's proposed 'dash for gas' is out to thousands of people. I'm proud of what we've achieved - but it's only the start of the battle for our energy future." (NDG protestor quoted in Wainwright 2012c)

The above figures were repeated across a number of media outlets and taken from NDG press releases and tweets. NDG's media output outlines how they: prevented a particular quantity of $\mathrm{CO}_{2}$ emissions; disrupted the building of new fossil fuel infrastructure and; produced a public spectacle that framed the building of new fossil fuelled power stations as a matter of public concern (RCP 2012).

$\mathrm{CO}_{2}$ emissions are used to mark a particular piece of energy infrastructure as politically important (stopping the chimney for just over a week produced a reduction of " 20,000 tonnes of $\mathrm{CO}_{2}$ "). The action is legitimated in mathematical terms, but these terms do not stand on their own. Rather they speak to an implicit referent - the total amount of reductions that are needed to address climate change as an issue, a figure that is either presented as a percentage - i.e., $80 \%$ on 1990 levels - or as a total in tonnes of $\mathrm{CO}_{2}$. The immediate outcome of the NDG action can be measured against this total as a sign of progress towards addressing the problem of climate change. Progress in this instance serves to legitimate the action by framing it as both practical (it works) and necessary (it needs to be done). There is also a comparative mathematics at work when the outcome of blockading one power station is compared to 465 cars being taken off the road, or one day of inactivity for the same power station is equivalent to the energy used in a house over 182 years as measure in terms of $\mathrm{CO}_{2}$. The framing effect of this comparison is to make cars and power stations fungible by disentangling them from their specific sociomaterial relations and making them legible as pieces of climate infrastructure. It also works to make it appear as though there is a consensus about the specific objectives of 
environmental politics as counting carbon in order to reduce carbon emissions (Wolsink 2010).

The mathematics of counting carbon enables action to be taken on climate change as an issue, first by making actions calculable and therefore legitimate and secondly by repoliticising climate change as a matter of public infrastructure and not private consumption. In this latter instance, the arithmetic of calculative activism has the effect of legitimating public infrastructure as a political target. If it is a scientific necessity to reduce carbon emissions, and such reductions overwhelmingly have to take place within and through infrastructure, then infrastructure is a legitimate target of protest (Vidal 2008). However, this move to politicize the conditions of life is at once undermined by the calculative framework of climate activism.

The carbon emissions prevented by NDG's occupation signified the potential reductions of carbon emissions that could result from blocking the building of the new power station. This potential reduction, made visible by the actual reduction that results from the action, only has value within a global accounting of greenhouse gas emissions. Framed by the scalar logic of climate change, the question of infrastructure is disentangled from other social considerations and subordinated to global carbon calculus. In this fashion counting carbon reinforces the autonomy of the global technosphere (Massey 2014) even as it subjects economic accounting to an atmospheric referent.

This scaling undermines the potential for enacting thick justice through infrastructural campaigns by introducing a particular kind of calculative pragmatism into environmental praxis where place is displaced by planet (Heise 2008), one that could be said to mobilise a "thin cosmopolitanism" (Dobson 2006) ${ }^{\mathrm{vi}}$ and where a kind of global expertise comes to stand in as the only legitimate form of political agency vis-à-vis climate change (Mitchell 2002:41). As such, while it is inaccurate to suggest, pace the postpolitical argument, that science undermines politics as a mode of social practice, it does suggest that the practice of counting carbon functions to produce and validate a specific set of political agencies that take up certain aspects of "high modernism" (Scott 1998:4), most notably the role of expertise, the proper scale of political intervention, and scientific rationalism as the legitimate analytical and political framework. These political agencies function to disable, obscure and invalidate other modes of political agency and non-expert modes of knowledge (Mitchell 2002:41).

While questions of alternative forms of life are often at the heart of infrastructural campaigns - how we farm, how we move, what should be sacrificed for how we live with climate infrastructure pragmatism supersedes such concerns. The forms of life climate infrastructure 'locks' us into are important primarily vis-à-vis greenhouse gas emissions; the need to reduce emissions frames justice as a secondary concern, one to be addressed after securing the necessary reduction in carbon emissions. Or, perhaps more accurately, it suggests justice will be an outcome of emissions reductions and 'getting the climate math right'.

\section{Slippery infrastructure}

"When we did the maths this morning and realised what an environmental impact we're making, it suddenly hit home just how important radical action like this can be." (NDG protestor quoted in OT 2012) 
Calculative activism as undertaken by NDG enables seeing infrastructure in a particular way. It makes some locations within the UK's climate infrastructure more important than others, worthier targets for political actions that others. Making climate infrastructure commensurate by counting carbon opens up the practical option of moving from abstract calculus to site-specific action. But this movement, this way of taking hold of climate infrastructure, is not without its ambivalences.

An encounter with a specific 'piece' of infrastructure, even at a discursive level, introduces an element of social friction (Tsing 2004). To consider the West Burton power station is to consider climate infrastructure as an element of a specific place. Taking up Doreen Massey's notion of place as a site of encounter (2014), what considering West Burton power station as a particular instantiation of climate infrastructure does is open up debate around the particular encounters is enables and produces.

Much of the debate that took place in the media during and after the action fell into what could be considered a classic trope of environmental reporting: the conflict between jobs and the environment. In a piece reporting on the protest, one newspaper article ended by making the economic stakes of the action clear:

"Work started on the $6600 \mathrm{~m}$ combined cycle gas turbine station in 2008, with some 1,000 jobs involved in construction, including a $19 \mathrm{~km}$ (12 mile) gas pipeline and generation equipment to supply power to about $1.5 \mathrm{~m}$ homes and businesses." (Wainwright 2012a)

In itself this debate is nothing new - such debates date back to the beginning of the modern environment movement (Hay 2002), if not earlier (Bonneuil and Fressoz 2016). Seen from the perspective of calculative activism such a conflict is often analysed as one between a scientifically-literate environmentalism and a labour movement captured by the capitalist ideology of limitless growth. And, often in the same breath, the conflict is seen as one between two political scales, the global and local, where it is assumed that the local will (indeed, must!) make way for the global. What I want to suggest here is that both arguments mobilise a common set of globalist logics, where the abstract, de-placed and global is both more powerful and more valid than what is cast or described as local (Gibson-Graham 2002; Massey 2014; Tsing 2004). I would suggest that calculative activism is precisely a means to enforce such a globalised scaling specifically against the frictions of situated encounters around climate infrastructure.

The encounters that make up the place of West Burton power station are not limited to those between NDG and the people employed by either the power company EDF or various construction companies building the power station. Also entangled are farmers, farmer organisations, people who live in the area around the power station, energy consumers, an array of local government organizations, regional business and government institutions, community and environmental groups, labour unions, political parties, environmental and climate scientists, journalists, the national government (from MPs and policy wonks to administrative workers and compliance officers) to the various institutions of the European Union. Just to name a few.

Counting carbon offers a means of smoothing over the vast array of potential (and actual) conflicts that emerge in and around the West Burton power station. Power generation in West Burton goes back to 1967 when a coal-fired power station 'next door' to the one contested by NDG activists was first commissioned. The company building the gas-fire power station, EDF, claims the commissioning phase of the new build dates 
back to 2007. In both instances the NDG actions come up against particular legacies of planning, construction, operation and governance as well as national programs and energy infrastructural demands. These legacies come with specific social-economic relations, ones that produce resistance to the idea of 'shutting down' the stations: from the involvement of local school children through the 'discovery centre' in the old coalfire power station to the people employed to build and operate the new station to the people and businesses who make use of the energy.

Counting carbon works to introduce a synoptic perspective (Scott 1998:11), one that invalidates and obscures a host of particular issues and other non-calculative processes and practices such as listed above. As Scott notes, "certain forms of knowledge and control require a narrowing of vision" (ibid). While there are many state-led projects that count carbon in order to produce climate change market regimes (Arora-Jonsson et al. 2015; Bohm, Murtola and Spoelstra 20012), my contention is that the synoptic perspective is not solely the province of state-making but rather as aspect of other political movements that seek to establish control over a terrain or space by framing the critical elements of that terrain legible in a specific way (ibid:4) ${ }^{\mathrm{vii}}$. The labour involved in making something legible is often a labour of simplification - of not only creating a hierarchy of values and producing some things as representable and others opaque (as either private, as inconsequential or as natural) but in actually shaping the social field in order to socially and materially simplify it (we could note here that the role of $\mathrm{CO}_{2}$ as a proxy acts on the disruption of the carbon cycle in a similar simplifying fashion towards similar pragmatic ends).

Scott sets out how the state makes society legible in much the same was as it makes nature legible, thus producing specific populations (Foucault 2007), separations (Mitchell 2002) and historical natures (Moore 2015). A key image in his archive is scientific forestry. Not only were new forms of measurement and analysis introduced in order to better manage state forests, the forests themselves were physically changed, with a greater uniformity of species and generational succession introduced to ease management. Here we could note the similarities in Scott's argument to accounts of governmentality in France in the eighteenth and nineteenth centuries by Foucault (2007), or, returning to the discussion of the constitution of climate change as a calculative problem (or factish) above, note the similarities between state-making and scientific knowledge production (Stengers 2000).

As argued by Scott, not every synoptic approach is violent (or even materially capable of such acts of violence). Violently remaking peoples and natures requires the addition of both what Scott calls a "high modernist ideology" - the muscular belief in a top-down, productivist and techno-scientific vision of progress that marries rational planning with fantasies of the mastery of nature - and an authoritarian state (1998:4). And while NDG have both a synoptic perspective and elements of a high-modernist perspective (though no more than elements I would suggest), they are certainly not a state-actor nor do they suggest they would like to be. Nor do they avoid engaging with workers or the local community - it is just that any engagement came after the fact of the occupation rather than as a central element of it, indicating a layering of priorities ${ }^{\text {viii }}$.

Nonetheless counting carbon does work to synoptically frame climate infrastructure. The global nature of climate change and the pressing urgency of it as an issue compel climate activists to take up the synoptic perspective of the state. To "see like a state" is not only a matter of making facts into particular kinds of concerns, ones that are framed as technical questions (Demeritt 2006); it is to produce a particular kind of political scale, 
one where the local is both produced as a specific political identity and cast as a reactionary ecological force. With climate change, what we see is the eclipse of the local as a site of political action: it has been measured in Parts Per Million and found wanting.

By making infrastructure measurable, the particularities of any given piece of infrastructure become subject to evaluation via $\mathrm{CO}_{2}$ emissions. The fungible nature of climate infrastructure renders the specificities of its entanglements and connections subject to pragmatic consideration, where pragmatism is always-already a matter of global concern. In this way justice becomes a matter of global calculus, as the costs and benefits of any given piece of infrastructure are measured in Parts Per Million (PPM) of $\mathrm{CO}_{2}$ on a global scale.

Thus the possibilities of addressing forms of life or ways of being in the world vis-à-vis a particular instantiation of infrastructure slip away under calculative pressure within a global arithmetic framework. Here the ambivalence of turning to specific pieces of climate infrastructure are cast aside - the lives affected, the specific visions and hopes for the future, the histories and ways of being in that place in the world are all negated in the synoptic carbon gaze. The rescaling of infrastructure from a situated to global (abstract) concern undoes our hold on it and our capacity to undertake the work of producing thick justice.

\section{Infernal arithmetic}

Thick justice requires us to be for some worlds and against others (Haraway 1997:47). It is a question of making alliances and ecologies, itself a polarizing labour that turns on the question of who or what we care for and how (Bellacasa 2012). If environmentalists are to consider climate change as a problem of infrastructure, then addressing climate change will require changing the sociotechnical arrangements of inhabited existing worlds, foregrounding the question of what lives 'we' wish to be for and what forms of life will be rendered unviable and unliveable.

The infrastructure that underpins modern life in the UK is not a neutral tool but a series of sociotechnical arrangements that re/produce particular forms of life. Infrastructure is an object, the relation between objects and the grounds on which other objects operate (Larkin 2013:329). Infrastructure is an ambience within which we are enmeshed. It is not only a mode of socio-political management and rule (Anand et al. 2012), it is part of the specific capacities and agencies we take for granted or naturalise (Mitchell 2002:80) - at least until they break down (Jackson 2014). As such to contest infrastructure is to contest the very constitution of people's lives. These lives may be in a state of cruel optimism (Berlant 2011) or toxified by the waste of late liberal energy technologies (Fortun 2014), but this does not make people any less attached to them. Indeed as Lauren Berlant suggests the lack of other visible or viable forms of life may make people all the more attached to their existing lives, dreams, hopes and futures, even if this means knowingly embracing a climate change future (2011). It is thus crucial to directly address the question of the intimate transformation of people's forms of life and not approach them as secondary concerns to the counting of carbon.

Returning to the power station, blocking the construction of the new gas-fire power station will put into question the incomes and wealth of a number of people (as well as their future careers and familial prospects), the socio-economic status of a region and the energy supply of a national grid. While it is often argued that climate change is an issue 
that affects everyone and that to adequately address climate change will be to universal benefit, not everyone will be equally affected by how climate change is resolved as an issue. Where some people may benefit, some will not. Beyond the immediate questions of infrastructure there are broader considerations of the kinds of ways of life enabled by current energy infrastructure that may not be viable or possible if energy production was changed in a manner consistent with tackling climate change as an issue.

It is rare that environmentalists will openly talk of what will be lost through successful efforts to address climate change. Often the talk is of green jobs, or increased happiness, of better health and brighter futures, and for good reason. Common sense suggests that campaigning on the basis of making people's lives measurably worse would not be a recipe for success. The proposals for "prosperity without growth" (Jackson 2011) or shorter working weeks (Coote, Franklin and Simms 2010) are recognitions of the fact that what is required is a plan to 'de-grow' the economy without necessarily introducing social austerity.

These proposals set out from the abstract calculus of carbon and arrive at national plans for tackling climate change in a just fashion. Justice here is a matter of how the transformation is arranged, of how the counting of carbon takes place: it is about the even distribution of numbers. As such the difficult question of what constitutes justice is evaded. More to the point, the politics of thick justice is avoided completely as it is already assumed that some lives will cease to be possible and must be pragmatically scarified in order to tackle climate change.

I am not suggesting here that existing ways of life in the global North should not be disturbed in order to tackle climate change, or that climate change is not a massive and pressing socio-ecological concern. I am arguing that the constitution of climate change as a matter of counting carbon reduces the substance of political questions to pragmatic arithmetic. Justice becomes a matter of calculation and not of engaging in the difficult political work of figuring out how to live in the world, where what is at stake is recognized to be the continued or possible existence of forms of life. As such the global political scale of climate change is reproduced through calculative activism at the expense of thick justice.

Given how climate change is constituted as a problem, the conflict appears as an infernal alternative, a situation that seems "to leave no other choice than resignation or a slightly hollow sounding denunciation" (Stengers and Pignarre 2011:25). You can choose to engage in the messy politics of constituting place and produce thick justice or you can adequately deal with climate change as an issue, and leave political concerns for after that problem is solved. You can have justice and an unlivable world, or you can solve climate change and impose green austerity. You can't have both.

The cost of counting carbon is the loss of the particular (Jasanoff 2010), and with it the loss of the capacity to pose questions of thick justice. This double loss is a function of the way in which the problem of climate change is constituted. As a global issue, one that promises catastrophe on unimaginable scales, it functions to subordinate questions of how we should or can live to questions of how we are to manage climate change.

\section{Re-scaling climate change}

Donna Haraway suggests that we need to be attentive to the ways in which our concepts work: what they enable and disable as modes of engaging with the world (1997:36). As a mathematical description of the breakdown in the carbon cycle, the concept of climate 
change enables us to take hold of the problem of global warming through a worldspanning technical apparatus (Edwards 2010) and to subject it to policy analysis and political debate (Demeritt 2006). At the same time the scale-making of climate change renders questions of thick justice inaccessible and de-situates political agency, making it a matter of global political action. The production of a sense of planet (Heise 2008) as a means of 'seeing' climate change and working to mitigate it implies a global mode of politics and the capacity to see like a state.

Climate change activism as an expression of a global politics sets out to overcome the friction of situated encounters that may block, slow down or alter action deemed necessary to arrest climate change (Tsing 2004:5). The global synoptic perspective of climate activism articulates the frictions of localized engagements as impediments to effective action on climate change. Pragmatism manifests as unscientific compromise; compromise that endangers all life on earth in the face of the looming climate catastrophe.

Such a synoptic perspective undermines questions of thick justice. It does not entirely silence such questions however. Within any material encounter with energy infrastructure, as in NDG's action, it is impossible to not to engage in debate or conflict around the conditions of people's lives: how they can and will be able to live, the capacities they have or will have, who they can or can't be. Indeed, after the NDG action started these are exactly the sorts of encounters that begun to take place. Rather than maintaining that these situated concerns for jobs, energy, ways of life, etc are necessarily regressive or anti-environmental, or that they can be tackled without there being any conflict with a reduction in carbon emissions, there needs to be a sustained engagement with questions of how we are to live without the assumption that the situated or 'local' must necessarily be subordinated to the global (Gibson-Graham 2002). Better yet, infrastructure could provide the opportunity for foregoing the local/global dyad in favour of a politics that 'stays with the trouble' of specific infrastructures (Haraway 2014). At stake here are the questions: is it possible to realize the sort of open "militant particuarlism" that David Featherstone advocates (2005) through climate infrastructure despite the framing effects of climate change as a political problem? Is it possible to take hold of the problem of climate change without counting carbon or mobilizing a global political scale? Is it possible to make climate change speak otherwise?

This would not mean foregoing a planetary or biospheric (in contrast to global) perspective of climate change. Rather, it could mean incorporating climate change into the messy negotiations that surround the question of how want to inhabit the future in place. Politics in this instance is not only a matter of being for some worlds against others, but for some scales against others. The rescaling of agency vis-à-vis climate change is already taking place as infrastructures moves to the centre of political action. Pipelines, oil and gas fields, power stations and more are all slowly moving to the centre of climate change politics. In doing so, it will be increasingly difficult to escape the "grip of the encounter" (Tsing 2004:5) where questions of how we are to live cannot be referred to a global arithmetic or avoided.

Such an encounter works to reveal climate change not as a global problem, but one that emerges piece by piece through specific encounters, and thus one amenable to situated works of activism. Just as capitalism is constructed piece by piece as a globalizing project, so too is climate change produced through specific labours, networks, conflicts and projects as a global object of concern. Rather than uncritically accept the inheritance of such globalizing projects, a shift to more intimate modes of infrastructural activism could 
open up the construction and reproduction of both climate change as a biospheric state and, it might be said, capitalism as an organizing force of the current world-system. 


\section{Bibliography}

Adam, David, and Mark Tran. 2009. "Kingsnorth power station plans shelved by E.ON." in The Guardian.

Anand, Nikhil , Johnathan Bach, Julia Elyachar, and Daniel Mains. 2012. "Infrastructure: Commentary from Nikhil Anand, Johnathan Bach, Julia Elyachar, and Daniel Mains."." in Curated Collections. Cultural Anthropology Online.

Anderson, Kevin. 2012. "Climate Change going beyond dangerous - Brutal numbers and tenuous hope." Development Dialogue September 2012(What Next Volume III - Climate, Development and Equity):16-40.

—. 2013. "Avoiding dangerous climate change demands de-growth strategies from wealthier nations." in Kevin Anderson.

Anderson, Kevin, and Alice Bows. 2010. "Beyond 'dangerous' climate change: emission scenarios for a new world." Philosophical Transactions of the Royal Society A: Mathematical, Physical and Engineering Sciences 369(1934):20-44.

Archer, David. 2009. The Long Thaw: How humans are changing the next 100,000 years of the earth's climate. Oxford: Princeton University Press.

Arora-Jonsson, Seema, Lisa Westholm, Beatus John Temu, and Andrea Petitt. 2015. "Carbon and Cash in Climate Assemblages: The Making of a New Global Citizenship." Antipode 48(1):74-96.

Barry, J, and S Quilley. 2008. "Transition Towns: "Survival", "resilience" and sustainable communities - Outline of a research agenda." Advances in Ecopolitics 2:14-37.

Bellacasa, Maria Puig de la. 2012. "Nothing comes without its world': thinking with care." The Sociological Review 60(2):197-216.

Bergman, Noam. 2014. "Climate Camp and public discourse of climate change in the UK." Carbon Management 5(3):1-10.

Berlant, Lauren. 2011. Cruel Optimism: Duke University Press.

Blok, Anders, Moe Nakazora, and Brit Ross Winthereik. 2016. "Infrastructuring Environments." Science as Culture 25(1):1-22.

Bohm, Steffen, Anna-Maria Murtola, and Sverre Spoelstra. 20012. "The atmosphere business." ephemera: theory \& politics in organisation $12(1 / 2)$.

Bomberg, Elizabeth. 2012. "Moving beyond the impasse: climate change activism in the US and the EU." Pp. 123-41 in Governance, Democracy and Sustainable Development: Moving Beyond the Impasse, edited by Oluf Langhelle James Meadowcroft, Audun Rudd. Cheltenham: Edward Edgar Publishing.

Bonneuil, Christophe, and Jean-Baptiste Fressoz. 2016. The Shock of the Anthropocene: The Earth, History and Us. London: Verso.

Bowman, Andrew. 2010. "Are we armed only with peer reviewed science? The scientization of politics, trust, risk and the environmental movement." Pp. 173-96 in Future ethics: climate change and the apocalyptic imagination, edited by Stefan Skrimshire. London: Continuum.

Boyer, Dominic. forthcoming. "Revolutionary Infrastructure." in Infrastructures and Social Complexity: A Routledge Companion, edited by Penny Harvey, Casper Bruun Jensen, and Atsuro Morita. New York: Routledge.

Braun, Bruce, and Sarah J. Whatmore (Eds.). 2010. Political Matter: Technoscience, Democracy, and Public Life. Minneapolis: University of Minnesota Press.

Bryant, Gareth. 2016. "The Politics of Carbon Market Design: Rethinking the Techno-politics and Post-politics of Climate Change." Antipode.

Camp, Climate. 2009. "About us." http:// climatecamp.org.uk/.

—. 2010. "Where Next Minutes." http://climatecamp.org.uk.

Carter, Lawrence. 2012. "Why I helped occupy a gas power station in the name of a better future." Blue \& Green Tomorrow.

Castree, Noel. 2014. Making sense of nature: Representation, politics and democracy. New York: Routledge.

Chatterton, Paul, David Featherstone, and Paul Routledge. 2013. "Articulating Climate Justice in Copenhagen: Antagonism, the Commons, and Solidarity." Antipode 45(3):602-20. 
Clark, Timothy. 2012. "Scale: Derangements of Scale." Pp. 148-66 in Telemorphosis: Theory in the Era of Climate Change, edited by Tom Cohen. Ann Arbor: Open Humanities Press.

Coote, Anna, Jane Franklin, and Andrew Simms. 2010. "21 hours: Why a shorter working week can help us all to flourish in the 21st century." New Economics Foundation.

Cornerhouse. 2010. "Commodity Fetishism in Climate Science and Policy." in Corner House Briefing Paper.

Crouch, Colin. 2012. The Strange Non-Death of Neoliberalism. Cambridge: Polity.

Dean, Jodi. 2009. Democracy and other Neoliberal fantasies: Communicative capitalism and Left politics. London: Duke University Press.

Demeritt, David. 2001. "The Construction of Global Warming and the Politics of Science." Annals of the Association of American Geographers 91(2):307-37.

- 2006. "Science studies, climate change and the prospects for constructivist critique." Economy and Society 35(3):453-79.

Dobson, Andrew. 2006. "Thick Cosmopolitanism." Political Studies 54:165-84.

Dryzek, John S. 2005. The Politics of the Earth: Environmental Discourses. Oxford: Oxford University Press.

Edwards, Paul N. 2010. A V ast Machine: Computer Models, Climate Data, and the Politics of Global $W$ arming. Cambrudge: The MIT Press.

Evans, Brad, and Julia Reid. 2014. Resilient Life: The art of living dangerously. Cambridge: Polity.

Featherstone, David. 2005. "Towards the Relational Construction of Militant Particularisms: Or Why the Geographies of Past Struggles Matter for Resistance to Neoliberal." Antipode 37(2):250-71.

- 2013. "The Contested Politics of Climate Change and the Crisis of Neo-liberalism." ACME:An International E-Journal for Critical Geographies 12(1):44-64.

Featherstone, David, Anthony Ince, Danny Mackinnon, Kendra Strauss, and Andrew Cumbers. 2012. "Progressive localism and the construction of political alternatives." Transactions of the Institute of British Geographers 37(2):177-82.

Feigenbaum, Anna, Fabian Frenzel, and Patrick McCurdy. 2013. Protest Camps. London: Zed Books.

Fortun, Kim. 2001. Advocacy after Bhopal. London: University of Chicago Press.

—. 2014. "From Latour to late industrialism." Hau: Journal of Ethnographic Theory 4(1):309-29.

Foucault, Michel. 2007. Security, Territory, Population. New York: Palgrave Macmillan.

Frenzel, Fabian. 2014. "Exit the system? Anarchist organisation in the British climate camps." Ephemera 14(4):901-21.

Furlong, Kathryn. 2010. "Small technologies, big change: Rethinking infrastructure through STS and geography." Progress in Human Geography 35(4):460-82.

Gibson-Graham, J.K. 2002. "Beyond Global vs. Local: Economic politics outside the binary frame." in Geographies of power: Placing scale, edited by Andrew Herod and Melissa W. Wright. Oxford: Blackwell Publishing.

Hamilton, Clive. 2010. Requiem for a species: Why we resist the truth about climate change. Sydney: Allen \& Unwin.

Haraway, Donna J. 1991. Simians, Cyborgs and Women: The Reinvention of Nature. Oxon: Routledge.

—.1997.Modest_Witness@Second_Millennium.FemaleMan_Meets_OncoMouse. London: Routledge.

- 2014. "Anthropocene, Capitalocene, Chthulucene: Staying with the Trouble." in Arts of Living on a Damaged Planet. Santa Cruz, USA

Harding, E. 2015. "Prefiguration versus the "Reformist Drift" in the Camp for Climate Action." Capitalism Nature Socialism 26(4):141-57.

Harvey, Fiona. 2015. "UN publishes draft of slimmed-down Paris climate change deal." in The Guardian.

Hay, Peter. 2002. Main Currents in Western Environmental Thought. Sydney: UNSW Press.

Heise, Ursula K. 2008. Sense of Place and Sense of Planet: The Environmental Imagination of the Global. Oxford: Oxford University Press.

Hope, Mat. 2014. "Public support for gas power rises as concern about climate change dips." The Carbon Brief.

Howe, Cymene, Jessica Lockrem, Hannah Appel, Edward Hackett, Dominic Boyer, Randal Hall, Matthew Schneider-Mayerson, Albert Pope, Akhil Gupta, Elizabeth Rodwell, Andrea 
Ballestero, Trevor Durbin, Fare`s el-Dahdah, Elizabeth Long, and Cyrus Mody. 2015. "Paradoxical Infrastructures: Ruins, Retrofit, and Risk." Science, Technology, \& Human Values:1-19.

Hulme, Mike. 2009. Why we disagree about climate change: Understanding controversy, inaction and opportunity. Cambridge: Cambridge University Press.

Inman, Mason. 2010. "Has the World Already Passed "Peak Oil"?": National Geographic.

International, Friends of the Earth. 2009. "UN Climate Conference closes without adopting 'Copenhagen accord'." Friends of the Earth International.

Jackson, Steven J. 2014. "Rethinking Repair." in Media Technologies: Essays on Communication, Materiality and Society, edited by Tarleton Gillespie, Pablo Boczkowski, and Kirsten Foot. Cambridge: MIT Press.

Jackson, Tim. 2011. Prosperity without Growth: Economics for a Finite Planet. London: Routledge. Jasanoff, Shelia. 2010. "A New Climate for Society." Theory, Culture \& Society 27(2-3):233-53.

Jasiewicz, Ewa. 2012. "Why I'm occupying a gas-fired power station chimney." in Comment is free: The Guardian.

Jensen, Casper Bruun, and Atsuro Morita. 2015. "Infrastructures as Ontological Experiments." Engaging Science, Technology, and Society 1:81-87.

Kenis, Anneleen. 2014. "Climate change and post-politics: Repoliticizing the present by imagining the future?" Geoforum 52:148-56.

Klein, Naomi. 2014. This changes everything: Capitalism vs the climate. New York: Simon \& Schuster.

Larkin, Brian. 2013. "The Politics and Poetics of Infrastructure." Annual Review of Anthropology 42:327-43.

Latour, Bruno. 2004a. Politics of Nature: How to Bring the Sciences into Democracy: Harvard University Press.

—. 2004b. "Why Has Critique Run out of Steam? From Matters of Fact to Matters of Concern." Critical Inquiry 30(Winter 2004):225-48.

-. 2010. On the Modern Cult of the Factish Gods. London: Duke University Press.

Linebaugh, Peter. 2006. The London Hanged: Crime And Civil Society In The Eighteenth Century. London: Verso.

Luke, Timothy. 2015. "The climate change imaginary." Current Sociology 63(2):280-96.

Lynas, Mark. 2008. Six Degrees: Our Future on a Hotter Planet. London: Harper Perennial.

MacKinnon, Danny, and Kate Driscoll Derickson. 2013. "From resilience to resourcefulness: A critique of resilience policy and activism." Progress in Human Geography 37(2):253-70.

Marx, Karl. 1990. Capital Volume 1. London: Penguin.

Massey, Doreen. 2014. For Space. London: SAGE.

McCarthy, James. 2013. "We have never been "Post-political"." Capitalism, Nature, Socialism 24(1):19-25.

McGrath, Matt. 2013. "Are public attitudes to climate change as fickle as the weather?": BBC.

McGregor, Callum. 2015. "Direct climate action as public pedagogy: the cultural politics of the Camp for Climate Action." Environmental Politics 24(3).

McKibben, Bill. 2010. Eaarth: making a life on a tough new planet. New York: Times Books.

—. 2013. "Global Warming's Terrifying New Math." in Rolling Stone.

Mitchell, Timothy. 2002. Rule of Experts: Egypt, Techno-Politics, Modernity. Berkeley: University of California Press.

Monbiot, George. 2006. "An 87\% Cut by 2030." in The Guardian.

-. 2007. Heat: How we can stop the planet burning. London: Penguin.

-. 2012. "No Dash for Gas - the new, chimney-climbing face of climate direct action." in The Guardian.

Moore, Jason. 2015. Capitalism in the Web of Life: Ecology and the Accumulation of Capital. London: Verso.

Neocleous, Mark. 2013. "Resisting Resilience." Radical Philosopby 178(Mar/Apr 2013).

Neville, Kate J., and Erika Weinthal. 2016. "Scaling up site disputes: strategies to redefine 'local' in the fight against fracking." Environmental Politics 25(4):569-92.

North, Peter. 2011. "The politics of climate activism in the UK: a social movement analysis." Environment and Planning A 43(7):1581 - 98. 
North, Peter, and Noel Longhurst. 2013. "Grassroots Localisation? The Scalar Potential of and Limits of the 'Transition' Approach to Climate Change and Resource Constraint." Urban Studies 50(7):1423-38.

Noys, Benjamin. 2010. The Persistence of the Negative: A Critique of Contemporary Continental Theory. Edinburgh: Edinburgh University Press.

Oreskes, Naomi, and Erik M. Conway. 2011. Merchants of Doubt: How a Handful of Scientists Obscured the Truth on Issues from Tobacco Smoke to Global Warming. New York: Bloomsbury Press.

OT. 2012. "Demonstrators Prevent 10,000 Tonnes of CO2 Entering Atmosphere." Occupied Times.

Paget, Antonia. 2012. "Protesters Occupy Chimney At EDF Power Station." Impact: the University of Nottingham's Student Magazine: University of Nottingham Student Union.

Papadopoulos, Dimitris. 2010. "Insurgent Posthumanism." ephemera: theory \& organisation in politics 10(2):134-51.

—. 2014. "Politics of Matter: Justice and Organisation in Technoscience." Social Epistemology: A Journal of Knowledge, Culture andPolicy 28(1):70-85.

Parenti, Christian. 2011. Tropic of Chaos. Climate Change and the New Geography of Violence. New York: Nation Books.

Plows, A. 2000. "Collective Identity through Collective Action: Environmental Direct Action in Britain." in Political Studies Association 50th Annual Conference. London.

Plows, Alexandra. 2008. "Towards an Analysis of the 'Success' of UK Green Protests." British Politics 3:92-109.

Povinelli, Elizabeth. 2011. Economies of Abandonment. Social Belonging and Endurance in Late Liberalism. London: Duke University Press.

Power, Reclaim the. 2016. "We shut down the UK's largest coal mine."

RCP. 2012. "Press release: Campaigners from No Dash for Gas abseil 90m down power station chimney to end 7 day occupation." Reclaim the Power.

Reuters. 2015. "Climate pledges by 140 countries will limit global warming - but not enough." in The Guardian.

Rogers, Joel Faulkner. 2013. "Talking trust on climate science." Cambridge: YouGov.

Rootes, Christopher. 2011. "New Issues, New Forms of Action? Climate Change and Environmental Activism in Britain." Pp. 46-68 in New Participatory Dimensions in Civil Society, Professionalization and Individualized Collective Action, edited by Jan W. van Deth and William A Maloney. London: Routledge.

Saunders, Clare. 2012. "Reformism and radicalism in the Climate Camp in Britain: benign coexistence, tensions and prospects for bridging." Environmental Politics 21(5):829-46.

Saunders, Clare, and Stephan Price. 2009. "One person's eu-topia, another's hell: Climate Camp as a heterotopia." Environmental Politics 18(1):117-22.

Schlembach, Raphael. 2011. "How do radical climate movements negotiate their environmental and their social agendas? A study of debates within the Camp for Climate Action (UK)." Critical Social Policy:22.

Schlembach, Raphael, Ben Lear, and Andrew Bowman. 2012. "Science and ethics in the postpolitical era: strategies within the Camp for Climate Action." Environmental Politics 21(5).

Scott, James C. 1998. Seeing Like a State: How Certain Schemes to Improve the Human Condition Have Failed. London: Yale University Press.

Sealey-Huggins, Leon Ayo 2016. "Depoliticised activism? Ambivalence and pragmatism at the COP16." International Journal of Sociology and Social Policy 36(9/10):695 - 710.

Seel, B, M Paterson, and B Doherty (Eds.). 2000. Direct Action in British Environmentalism. London: Routledge.

Shackley, Simon, and Brian Wynne. 1996. "Representing Uncertainty in Global Climate Change Science and Policy: Boundary-Ordering Devices and Authority." Science, Technology \& Human Values 21(3):275-302.

Shift, and Dysophia. 2010. "Criticism without Critique: A Climate Camp Reader." Shift Magazine / Dysophia production.

Spratt, Stephen, Andrew Simms, Eva Neitzert, and Josh Ryan-Collins. 2009. "The Great Transition." edited by New Economics Foundation. London: New Economics Foundation. 
Star, Susan Leigh, and Karen Ruhleder. 1996. "Steps Toward an Ecology of Infrastructure: Design and Access for Large Information Spaces." Information Systems Research 7(1):11134.

Stengers, Isabelle. 2000. The Invention of Modern Science. London: University of Minnesota Press.

Stengers, Isabelle, and Phillipe Pignarre. 2011. Capitalist Sorcery: Breaking the Spell. New York: Palgrave Macmillan.

Stern, Nicholas. 2006. "The Economics of Climate Change: The Stern Review." London: HM Treasury.

Swyngedouw, Erik. 2008. "Impossible Sustainability and the Post-Political Condition." Pp. 13-39 in Sustainable Development, edited by D Gibbs and R Krueger. New York: Guilford Press.

—. 2010. "Apocalypse Forever? Post-political Populism and the Spectre of Climate Change." Theory, Culture \& Society 27(2-3):213-32.

-. 2013. "The Non-political Politics of Climate Change." ACME: An International E-Journal for Critical Geographies 12(1):1-8.

Tsing, Anna. 2004. Friction: An Ethnography of Global Connection. Princeton: Princeton University Press.

Valentine, J. 2005. "Rancière and Contemporary Political Problems." Paragraph 28(1):4-59.

Vidal, John. 2008. "Not guilty: the Greenpeace activists who used climate change as a legal defence." in The Guardian.

Vidal, John, Allegra Stratton, and Suzanne Goldenberg. 2009. "Low targets, goals dropped: Copenhagen ends in failure." in The Guardian.

Wainwright, Martin. 2012a. "Climate activists occupy West Burton gas power station." in The Guardian.

—. 2012b. "No Dash for Gas continues stand-off against police." in The Guardian.

—. 2012c. "No Dash For Gas ends the UK's longest power station occupation." in The Guardian.

Wall, D. 1999. Earth First and the Anti-Roads Movement. London: Routledge.

Weart, Spencer R. 2008. The Discovery of Global Warming. London: Harvard University Press.

Winner, Langdon. 1986. The Whale and the Reactor. Chicago: University of Chicago Press.

Wolsink, Maarten. 2010. "Contested environmental policy infrastructure: Socio-political acceptance of renewable energy, water, and waste facilities." Environmental Impact Assessment Review 30(5):302-11.

World Bank. 212. "Turn down the heat : why a $4^{\circ} \mathrm{C}$ warmer world must be avoided." Washington DC: World Bank.

\section{Endnotes}

\footnotetext{
${ }^{i}$ I would like to thank Anja Kanngieser, Stephanie Wakefield and Gavin Brown for their helpful comments and reading of an earlier draft of this paper. I would also like to acknowledge the Fisher Center, Hobart and William Smith Colleges, and the 2015-6 Fisher Center Fellows for both the time to work on the paper and innumerable useful discussions on many of the concepts and arguments therein.

ii This paper assumes some knowledge of climate change, including an awareness that $2^{\circ} \mathrm{C}$ is the internationally recognized level of dangerous climate change.

iii I would consider scientific realism to be a kind of naïve socio-technical realism, where a realist philosophical approach to the constitution of scientific facts is bound to an overly optimistic sense that scientific facts necessarily translate smoothly into matters of political concern. See Latour, Bruno. 2004b. "Why Has Critique Run out of Steam? From Matters of Fact to Matters of Concern." Critical Inquiry 30(Winter 2004):225-48. (do you need to put the whole reference in here? )

iv Hence the notable shift towards resilience as a container for ecological thought. See Evans, Brad, and Julia Reid. 2014. Resilient Life: The art of living dangerously. Cambridge: Polity, MacKinnon,
} 
Danny, and Kate Driscoll Derickson. 2013. "From resilience to resourcefulness: A critique of resilience policy and activism." Progress in Human Geography 37(2):253-70, Neocleous, Mark. 2013. "Resisting Resilience." Radical Pbilosophy 178(Mar/Apr 2013).

"I am not exploring the diversity of environmental and environmental justice movements in the global South in this paper. My focus in on opening up how climate change is constituted in as a problem by environmental activists in the Anglospheric global North. Given the at times hegemonic (or neo-colonial) role of Northern activists in global climate change policy and discourse construction, such a critique obliquely suggests the need to engage with non-Northern modes of environmental praxis and non-Northern environmental imaginaries, particularly as they engage with and critique climate science. In addition, I do not intend on rehearsing the various arguments for and against the concept of the global North (or South) in this paper. I am making use of the (rough) division to gesture towards a particular area as conceived of by environmentalists in countries such as the UK and USA, where talk of global North-South politics is part of the political and policy discourse.

vi Dobson sets out to articulate an alternative approach to cosmopolitanism that he names thick cosmopolitanism, one that overcome the separations of a global humanity without abolishing the specificity of place: that is, to construct a cosmopolitan politics that sets out from material connection, using global warming as a basis for such common grounding. I would suggest that such a project necessarily requires interrogating how the materiality of the common ground is constituted, and what forms of life and agency are enabled or disabled by such a constitution. vii This is not to claim that the presence of a synoptic perspective indicates a desire to occupy the state, to produce a state-power or of an orientation around the state as an organizational form (though it might). To see like a state is not to become the state.

viii There were several tweets by NDG indicating that some workers had contacted them offering support, but that making this support public would cost them their jobs. In addition, many of the activists involved have been and continue to be involved in community energy and climate campaigns. In this particular instance however, both worker and community engagement came after the occupation, no doubt in order to ensure the occupation took place but also indicating the prioritization of the occupation over engagement. 